ULUSLARARASI DIL, EDEBIYAT VE KÜLTÜR ARASTIRMALARI DERGISI
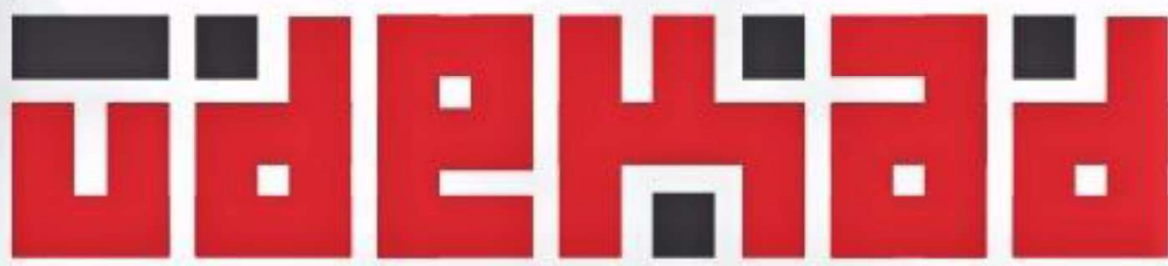

INTERNATIONAL JOURNAL OF LANGUAGE, LITERATURE AND GULTURE RESEARCHES

МЕЖДУНАРОДНЫЙ ЖУРНАЛ ЛИНГВИСТИЧЕСКИХ ЛИТЕРАТУРОВЕЛЧЕСКИХ И КУЛЬТУРОЛОГИЧЕСКИХ ИССЛЕЛОВАНИЙ

Vol: 4, Issue: 1, 2021

Sayfa-Page: $170-180$

E-ISSN: 2667-4262

\title{
DOMESTIC VIOLENCE AND DIVORCE IN SHERLOCK HOLMES STORIES
}

\section{SHERLOCK HOLMES HİKAYELERİNDE AİLE İÇİ ŞIDDET VE BOŞANMA \\ Sercan ÖZTEKIN*}

\begin{tabular}{|c|c|}
\hline ARTICLE INFO & ABSTRACT \\
\hline $\begin{array}{l}\text { Received: } 14.04 .2021 \\
\text { Accepted: } 25.06 .2021\end{array}$ & \multirow{3}{*}{$\begin{array}{l}\text { Sir Arthur Conan Doyle has been criticized for opposing to women's suffrage in the early } \\
\text { twentieth century and endorsing gender stereotypes in his works. However, his views on } \\
\text { women's rights were contradictory due to his campaign to reform British divorce laws which } \\
\text { were unequal for men and women. Along with obvious references to Victorian legal system } \\
\text { and social hierarchy, he displays family, marriage, and gender stereotypes as significant } \\
\text { subjects in some of his Sherlock Holmes stories. He draws attention to the social and legal } \\
\text { status of women in marriages, and the severity of laws about domestic violence and divorce. } \\
\text { This paper aims to propose a different approach to Sir Arthur Conan Doyle's views on these } \\
\text { laws and women's rights. With its focus on the issues of divorce and violence against women } \\
\text { in some Sherlock Holmes stories, it discusses how Doyle mirrors his defence on reform of } \\
\text { divorce laws and women's rights, especially in marriages. }\end{array}$} \\
\hline $\begin{array}{l}\text { Keywords: } \\
\text { Sir Arthur Conan Doyle, } \\
\text { Sherlock Holmes, } \\
\text { women's rights, } \\
\text { divorce, } \\
\text { domestic violence. }\end{array}$ & \\
\hline Research Article & \\
\hline
\end{tabular}

匈 Geliș: 14.04.2021

Kabul: $\quad 25.06 .2021$

\begin{tabular}{l}
\hline \hline Anahtar Kelimeler: \\
Sir Arthur Conan Doyle, \\
Sherlock Holmes, \\
kadın hakları, \\
boşanma, \\
aile içi şiddet. \\
\hline
\end{tabular}

Sir Arthur Conan Doyle, 20. yüzyılın başında kadınların süfrajet hareketine (oy hakkı arayışına) karşı çıktığı ve eserlerinde cinsiyet kalıplarını meşrulaştırdığı için eleştirilmiştir. Ancak, erkek ve kadın için eşit olmayan İngiliz boşanma yasalarının iyileştirilmesini desteklediği düşünülürse, kadın haklarıyla ilgili görüşlerinin çelişkili olduğu söylenebilir. Bazı Sherlock Holmes hikayelerinde Viktorya dönemindeki hukuk sistemi ve sosyal düzene açıkça bulunduğu atıflarla birlikte aile, evlilik ve cinsiyet kalıplarını da önemli konular olarak inceler. Kadınların evliliklerdeki toplumsal ve yasal konumlarına, aile içi şiddet ve boşanma ile ilgili yasaların katılığına da dikkat çeker. Bu çalışma, Sir Arthur Conan Doyle'ın kadın hakları ve sözü edilen yasalar ile ilgili görüşleri üzerine farklı bir bakış açısı sunmayı amaçlamaktadır. Çalışmada, boşanma ve kadına karşı şiddet konuları ele alınarak, Doyle'ın boşanma yasaları ve kadınların evliliklerdeki yasal haklarının düzenlenmesi gerektiği fikrini bazı Sherlock Holmes hikayelerinde nasıl yansıttığı incelenmektedir.

Araştırma Makalesi

\footnotetext{
* Öğr. Gör. Dr., Kocaeli University, The School of Foreign Languages, Kocaeli / Türkiye, E-mail: sercan.oztekinn@gmail.com. ORCID (D) https://orcid.org/0000-0003-1021-8460.

Bu makaleyi şu şekilde kaynak gösterebilirsiniz / To cite this article (APA):

Öztekin, Sercan (2021). "Domestic Violence and Divorce in Sherlock Holmes Stories". Uluslararası Dil, Edebiyat ve Kültür Araştırmaları Dergisi (UDEKAD), 4 (1): 170-180. DOI: http://dx.doi.org/10.37999/udekad.915553.
} 


\section{Introduction}

Strict moral and social codes prevailed in Victorian England, and the rigidity of these values shaped the concepts of family and marriage as well as laws about divorce and domestic violence. The patriarchal hegemony and women's vulnerable position compared to men brought about violence against women almost in all social classes of Victorian society. Although many women were abused by their husbands, this situation received too little attention during the Victorian age (Moon 2016: 3). It was mostly overlooked, and legal reforms were not enough to stop these offenses and protect women. Elizabeth Foyster (2005: 40-41) stresses that laws, by 1832, granted men power over their wives and they could beat their wives unless this violence was cruel and life threatening, so married women had to endure this and avoid reporting non-violent abuse. The effects of this legislation could be observed throughout the Victorian age despite some legal reforms like the 1878 Matrimonial Causes Act which allowed women to get away from their abusive husbands (Moon 2016: 7). The difficulty of getting a divorce was another reason why women had to abide domestic abuse in their marriages. Thus, Victorian conservative social and gender norms engendered inequality in the rights of women and laws about divorce.

Sir Arthur Conan Doyle, along with obvious references to Victorian legal system and social hierarchy, displays family, marriage, and gender stereotypes as significant subjects in some of his Sherlock Holmes stories. He draws attention to the situation of women in marriages and the severity of matrimonial laws. Some of these stories feature unfortunate characters who cannot get divorced and women who are abused by their husbands. Sherlock Holmes sometimes acts outside the law in order to bring justice for women, so this emphasizes ineffectual and inadequate judicial proceedings. In this way, Doyle shows that the justice system will not be adequate to protect women and their rights. Marital problems have not been studied in the Holmes stories in much detail, for many of these stories do not include such topics. Some scholars like Catherine Belsey (1996) and Jina Moon (2016) stress his traditional stance about women's rights. This paper offers a different perspective on Doyle's views about women in some of the Holmes narratives. Regarding gender perceptions and the situation of women in the Victorian age, it discusses how the Holmes stories mirror Doyle's defence on reform of divorce laws and women's rights, especially in marriages.

\section{Sir Arthur Conan Doyle on Divorce and Women's Rights}

As a typical late-Victorian male, Sir Arthur Conan Doyle was a defender of imperialism and Victorian conventions (Hodgson 2010: 392-393). He was opposed to women's right to vote, and this opposition has resulted in a failure to recognize that his views of women and women's rights were actually contradictory. That complexity is evident in his campaign to reform British divorce laws. As John A. Hodgson (2010: 393) argues, "he was an opponent of women's suffrage but also a supporter of divorce law reform". Although he is denounced for opposing women's suffrage movement in the early twentieth century, he states that he does not approve violence and harms caused by the women looking for improvements in their rights. Andrew Lycett (2007: 363) explains that Doyle's stance was firm after suffragists' violent protests in London in 1913 and their attempt for placing explosives near the house of Chancellor of 
Exchequer. Doyle believes that these kinds of protests should not be made violently by causing serious damage. That is the reason why he does not support women's suffrage movement, whereas he advocates equality and advances in the rights of married women.

Sherlock Holmes stories sometimes feature remarkable and unconventional women like Irene Adler in A Scandal in Bohemia (Frank 1996: 53). She is the most famous woman in the Holmes stories as a strong, independent, and resourceful character. However, because of his conventional ideas, Doyle is usually criticized for his stereotyped representations of women in these stories. Catherine Belsey (1994: 385) argues that Doyle presents women as insignificant in most of his works. Additionally, Lesli Favor (2000: 389) underlines Doyle's portraying women as silenced others under male hegemony, and they are "controlled, contained, and marginalized". Regarding the depiction of abused women as in need of protective men, Jina Moon criticizes Doyle for proposing that abused women should depend on "chivalrous" (2016: 13) men to escape from their brutal husbands. Nevertheless, women abused emotionally and physically bear further investigation in these works because Doyle tries to raise awareness about the situation of these women. He displays the hardships and disadvantages of rigid divorce laws and the issue of domestic violence which were generally overlooked even in the late nineteenth century. Unlike many critics have pointed out, these stories expose this state of affairs rather than perpetuate the ideals of womanhood.

Considering strict Victorian social norms and laws about marriage, Sir Arthur Conan Doyle deals with Victorian marital problems and divorce in some of his Holmes stories, such as "The Adventure of Black Peter" (1904), "The Adventure of Abbey Grange" (1904), and "The Devil's Foot" (1910). The Victorian idea of family and marriage as sacred was still prevalent in the Edwardian Era because divorce was still unquestionable as it was a shameful practice especially for the upper classes (O'Day 1979: 139). Although the Divorce and Matrimonial Causes Act of 1857 brought about changes in divorce and marriage laws, it was still based on gender bias. According to this law, as Gail L. Savage (1983: 103) points out, adultery could be the only ground for men to divorce their wives whereas women, to divorce their husbands, had to prove adultery together with some other offences such as cruelty or desertion. Moreover, basic principles of this law remained the same until the Divorce Act of 1937. As a member and later the president of the Divorce Reform Union which advocated less severe divorce laws, Doyle proposed that "the grounds for divorce should be the same for men and women, and should include adultery, cruelty, [...] and desertion" (Redmond 1993: 104) for both sides. Thus, he cannot be accused of devaluing women and endorsing their inferior status in his works. He mentions his first wife as the most significant person for the improvement of his creativity during the early years of their marriage and his writing career (Lycett 2007: 116). Happiness in marriage and the significance of women as powerful and effective agents in men's lives are indispensable elements of Doyle's ideas on women and marriage. As a result, it is not surprising that he criticizes the laws ignoring the rights and the position of women in matrimonial matters.

With reference to divorce, Christopher Redmond (1993: 124) expresses that "the problem of intolerable but indissoluble marriages" was on Doyle's mind partly because of his personal life. Doyle was in love with Jean Leckie while he was married to Louise Hawkins who was ill 
during the last ten years of her life and their marriage. He did not get divorced, albeit he and his wife did not have any relationship more than a doctor and a patient (Lycett 2007: 247). A divorce would possibly be a public scandal especially when his wife's health was in constant deterioration. A year after his wife's death, he got married to Jean. Therefore, his personal life was influential on his representations and subjects in his literary works. Andrew Lycett (2007: 60) states that Doyle had a dominant mother in the family, and normally he was prone to be supportive for women's equal social status in marriages. This background possibly influenced his opinions on equality between husbands and wives, and the necessity of mutual respect for a happy marriage. Furthermore, this shows why he might have got these challenging ideas that married women should be treated more equally. As Leslie Haynsworth suggests, the Holmes stories question "the various cultural values and beliefs that shape our ideas about normative [...] subjectivity" (2001: 463) instead of totally complying with them. Doyle was undoubtedly a questioner of conventional social norms although he was opposed to women's rights in constitutional matters like voting.

\section{Domestic Violence and Divorce in the Holmes Stories}

Doyle sheds a light on the issues of domestic violence and divorce in the Holmes stories. He often presents the most common reason for men's abusing their wives as drunkenness which is congruent with the traditional belief that men usually maltreat their wives when they are drunk. In "The Adventure of Black Peter", for instance, Peter Carey is described as "an intermittent drunkard" and a "perfect fiend" (Doyle 1930: 560) when he drinks heavily. He is commonly known for his bad temper and treating his wife and his daughter cruelly. In the story, it is stated that Peter Carey "was summoned once for a savage assault upon the old vicar" (Doyle 1930: 560) but it seems that he was never summoned for beating his wife and his daughter. Doyle shows the social attitude about domestic violence, as men could be brought to court when they attack another man, especially men of the church or the government. There is no legal sanction for his being cruel to his wife and daughter although he is known to "drive his wife and daughter out of the doors in the middle of the night and flog them through the park until the whole village outside the gates was aroused by their screams" (Doyle 1930: 560). It is explained by the narrator like a usual event, and not a police intervention is mentioned even though the incident was witnessed by everybody in the village. In addition, this passage demonstrates that neighbours do nothing about violence against women in marriages, which refers to the lack of public attention in this issue, not only the inadequacy of legal awareness and protection for women.

Doyle sometimes challenges established mindsets about why men abuse their wives. In the beginning of "A Case of Identity" (1891), Holmes and Watson discuss a newspaper story about the cruelty of a husband towards his wife. When Watson talks about the possible causes of this incident as "the other woman, the drink, the push, the blow, the bruise", Holmes corrects him by stating that "there was no other woman, and the conduct complained of was that he had drifted into the habit of [...] taking out his false teeth and hurling them at his wife" (Doyle 1930: 191). When Holmes says that the action is not "likely to occur to the imagination of the average story-teller" (Doyle 1930: 191), Doyle points out that people imagine only the mainstream ideas behind a case of a domestic violence. He defies the general belief that 
husbands abuse their wives when they are drunk and implies that men may mistreat their wives for no reason, just because they have bad temper or inclination to assert their superiority. Ginger Frost (2008: 12) indicates that violence, by some judges, was assumed to be the result of evil people in especially the working-class, and it was partly because "men viewed wives as their property, a sentiment that laws of England supported". Therefore, Doyle reveals how it is related to the fact that women were considered as physically weaker and socially inferior in the Victorian age.

"The Adventure of Abbey Grange" is a Holmes story which openly deals with upper class women who are abused physically by their husbands. Doyle (1930: 640) further highlights the connection between men's drunkenness and wife abuse because Inspector Hopkins describes Lord Brackenstall to Holmes and Watson in the following words:

"He was a good-hearted man when he was sober, but a perfect fiend when he was drunk, or rather when he was half-drunk, for he seldom really went the whole way. The devil seemed to be in him at such times, and he was capable of anything. From what I hear, in spite of all his wealth and his title, he very nearly came our way once or twice. [...] Then he threw a decanter at that maid, Theresa Wright - there was trouble about that. On the whole, and between ourselves, it will be a brighter house without him".

The final words in this passage subvert the ideal masculinity and marriage scheme in the Victorian period. Doyle puts forward that a husband does not always make the household a better and a brighter place. As it is observed in the extract above, Lord Brackenstall is characterized as 'the devil' which signifies his personality and the extent of cruelty he inflicts on people around him. Besides, he is identified with the words like "hound", "villain", and "brute" (Doyle 1930: 648-649) throughout the story. This shows how Doyle resists conventional perceptions about being an upper class gentleman because that is not the way a rich and privileged man like him is supposed to behave. Taking advantage of the serious effects of drinking on a person, Lord Brackenstall disguises his evil personality as a drunkard. In fact, Doyle proposes that men like him treat their wives badly because of the ideology held by the patriarchal order.

Lisa E. Surridge states that the Victorian age was ruled by the patriarchal order, which resulted in inadequate presence of women in social life and their "subordinate position, especially in marriage" (2005: 6). As a consequence, married women had to keep silent because their husbands were the only members who had financial power (Jina Moon 2016: 2). Similarly, married women from the upper classes had to remain silent and unwilling to divulge abuse in marriage because most of them did not have financial freedom and they had to keep their social reputation. Due to these reasons, legal legislations neglected the problem of domestic violence and reforms were delayed. Lisa E. Surridge (2005: 6) points out that 1828 Offenses Against the Person Act made the cases of domestic abuse legal issues for the working-class women. Additionally, domestic violence in the middle classes came into the public eye from the private sphere with the 1857 Divorce Act (Surridge 2005: 8). Nevertheless, the cases of this conjugal crime which were brought to courts were still very few. The absence of upper class women in 
these legal procedures also shows that domestic violence still was not associated with the upper classes.

Lord Brackenstall's abusing his wife reveals more about the condition of married women and matrimonial legal issues. Coming from Australia, his wife is a foreigner without any rights and anybody to support her in England, so he knows that she does not have many rights because of her gender and status as a foreigner. She is already inferior as a woman in the Victorian age, and her being a foreigner leaves her bereft of any rights. Lord Lyndhurst confirms this issue in a discussion during a Parliamentary debate in 1856 on reforming divorce laws and explains that the "wife is almost in a state of outlawry. She may not enter into a contract, or, if she does, she has no means of enforcing it. The law, so far from protecting, oppresses her. She is homeless, helpless, hopeless, and almost wholly destitute of civil rights" (quoted in Foyster 2005: 201). Regarding this argument, Doyle comments on the law and its inefficiency in protecting married women, especially the victims of abusive behaviour. When Lady Brackenstall is questioned, she says that she "was brought up in the freer, less conventional atmosphere of South Australia, and this English life, with its proprieties and primness, is not congenial to" (Doyle 1930: 638) her. In this way, she is introduced as a foreigner in England and to some devastating effects of Victorian conventions and their difference from the customs in her native country. In the following extract, she condemns British traditions and divorce laws harshly: "To be with such a man for an hour is unpleasant. Can you imagine what it means for a sensitive and highspirited woman to be tied to him for day and night? It is a sacrilege, a crime, a villainy to hold that such a marriage is binding. I say that these monstrous laws of yours will bring a curse upon the land -God will not let such wickedness endure" (Doyle 1930: 638). Here, Doyle makes his argument for reforms in the Divorce Act which is supposed to protect both men and women equally. There is an obvious criticism of English laws from a foreigner who lived in a freer country. Therefore, strict traditions and laws victimize women in unhappy marriages in which they may have to bear hardships. As women were not allowed to participate in any male dominated activity or occupation, they were not granted adequate legal rights in social life, marriage, and divorce. Women had to depend on their husbands for economic and social welfare, and they had to revert their properties and even their legal rights to their husbands' control until the late nineteenth century (Perkin 1989: 304-305). This marriage is like a prison for Lady Brackenstall because she is deprived of many rights, including divorce. In addition to her husband's higher social status, her being an outlander without proper legal rights is another reason why he abuses her and does not get punished for that.

In addition to defying conventional ideas on domestic violence, Doyle challenges the ideology that usually lower-class houses are places for abuse and violence in families. In the story, Lady Brackenstall is married to "the richest man in town", so Doyle (1930: 637) emphasizes the fact that domestic violence is not only limited to lower social classes. As Lisa E. Surridge (2005: 2-3) stresses, concerning domestic violence, the story urges reconsidering the "assumptions that wife beating occurs in the kitchen rather than the dining room". In upper class houses, kitchen could be related to lower-classes where servants spend most of their time, and the dining room is an upper class area where ladies host their guests. Lady Brackenstall is found in the kitchen, not in the dining or living room, which is an allusion to the established 
connection between domestic abuse and lower social status. In this way, she attempts to impute the attack to the burglars while trying to conceal the scars of the abuse. If she was in the living room, she would have to disclose the abuse as an embarrassing secret about her marriage. Holmes sees the scars and understands that she was not actually attacked by the burglars. Domestic violence was considered as "a lower-class phenomenon" even by most MPs in the Victorian age (Surridge 2005: 107). However, Doyle underlines that the cases of domestic violence occur in upper classes, too.

Doyle makes a very detailed description of inside the house in Abbey Grange when Holmes and Watson visit the crime scene for inspection. As Surridge (2005: 240) points out, Doyle invites readers inside the house in this scene and wants them to be aware of what might happen in houses like this. Readers penetrate the house with Holmes, not just watch the happenings passively. Jina Moon (2016: 8) suggests, by reading literary works like that, the readers become "aware of the harm done by domestic violence", and it helps transform social attitudes about such issues. Doyle raises awareness about unhappy marriages and domestic violence in houses like this and implies the need for more public and legal attention for the sake of improving women's situation in social and legal terms.

Along with his drawing attention to the necessity of legal reforms about abused women's rights, Doyle clearly portrays the effects of the abuse on Lady Brackenstall. He explicates that her "sufferings were physical as well as mental, for over one eye rose a hideous, plum-coloured swelling" (Doyle 1930: 637). No matter how badly she was treated, Holmes recognizes that Lady Brackenstall's "quick, observant gaze [...] showed that neither her wits nor her courage had been shaken by her terrible experience" (Doyle 1930: 637). Although she is an abused woman, Doyle pictures her as a courageous and clever woman, which violates conventional understandings of gender stereotypes. Leslie Haynsworth (2001: 463) states that Sherlock Holmes stories present fictional accounts which oppose Victorian principles and complicate gendered norms. Lady Brackenstall looks strong in spite of the trauma she has recently experienced. She is quick minded enough to show the murder of her husband like an attack from the burglars.

When Lady Brackenstall gives her testimony about what happened to her with the burglars, she explains the physical violence as if she was assaulted by the burglars. In fact, all the scars were done by her husband. It can be understood that Doyle wants us to feel the same way when a woman is violently abused by her husband, not only by strangers or criminals. It means that men are as guilty as heartless criminals when they physically abuse their wives. Additionally, the murderers of Lord Brackenstall are not the burglars, but Captain Crocker whom Lady Brackentsall met on the ship when she was coming to England from Australia but never reciprocated his love for her. On the night in question, he comes to their house just to see Lady Brackenstall, then her husband wakes up and sees them talking. After that, he is killed "with his own poker" (Doyle 1930: 637) by the Captain in the fight between the two men. In this way, the Captain saves his beloved from such a cruel husband. He speaks of Lady Brackenstall as "Mary" by not using her late husband's "accursed name" (Doyle 1930: 648). Along with Captain's hatred for Lord Brackenstall, this insult to his name can be read as a criticism of so-called wealth and status. That is to say, men with upper social status may cause 
harm and misery in a woman's life as well, and their privileged names do not always mean gentility.

When Holmes questions Lady Brackenstall, he is very kind and understanding to her. $\mathrm{He}$ says that he wants to "make things easier" for her because she is "a much-tried woman" (Doyle 1930: 645). He does not blame her for her husband's death yet empathizes with her and her suffering. It can be observed that Doyle is very affectionate and sympathetic to women abused by their husbands in unhappy marriages. Andrew Lycett (2007: 344) explains that Doyle sympathized highly with the "people locked in unhappy marriages", and this stance led him to take an active role in Divorce Law Reform Association. In addition to Captain Crooker, Sherlock Holmes himself embodies this benevolent type of masculinity. In "Charles Augustus Milverton" (1904), Holmes does not hesitate to help a woman thinking that "a gentleman should not lay much stress upon this [personal risk] when a lady is in most desperate need of his help" (Doyle 1930: 576). Through the feelings aroused by the maltreatment of Lady Brackenstall and the Captain's possible victimization by British laws, Holmes decides to take an extra-legal action: "Once or twice in my career I feel I have done more real harm by my discovery of a criminal than he ever had done by his crime. I have learned caution now, and I had rather play tricks with the law of England than with my own conscience" (Doyle 1930: 646). Violating laws here makes Holmes feel more relieved than taking legal proceedings against the Captain. He knows that announcing him as the murderer of Lord Brackenstall will not help him; on the contrary, he will be imprisoned for a long time. Because he sees the cruelty of Lord Brackenstall, Holmes decides to hold a mock trial for justifying Captain's killing him: "See here, Captain Crocker, we'll do this in due form of law. You are the prisoner. Watson, you are a British jury, [...]. I am the judge. Now, gentlemen of the jury, you have heard the evidence. Do you find the prisoner guilty or not guilty?" When Watson responds, "Not guilty, my lord," Holmes rules, "Vox populi, vox Dei. You are acquitted, Captain Crocker" ". (Doyle 1930: 650). By letting Lord Brackenstall's murderer free after this mock trial, Doyle seems to propose that abusers should receive what they deserve until these laws about domestic violence are improved. Doyle demonstrates that Lord Brackenstall got his deserts by being killed. Therefore, showing that such crimes sometimes should be judged in extra-legal ways, Holmes decriminalizes the murder of a cruel and abusive husband. In other words, it is observed that murdering an abuser is not more criminal and violent than abusing a wife.

Regarding legal proceedings about the Captain's situation, Holmes also declares, "I' $m$ not sure that in defence of your own life your action will not be pronounced legitimate" (Doyle 1930: 649). Upon discharging him, there is a criticism of inefficient and biased British legal system. Captain Crooker would be possibly punished harshly because of killing Lord Brackenstall, a member of the upper class. No matter what the reason is, murdering a citizen with higher social status is more intolerable than killing an ordinary person. That is why Doyle points out the fact that laws cannot protect Captain Crooker even though he killed a cruel and abusive man. When Holmes says, "So long as the law does not find some other victim you are safe from me" (1930: 650), Doyle clarifies that the law always finds a victim whether they are really guilty or not. As the murderer of abusive Lord Brackenstall, Holmes even lets the Captain to "[c]ome back to this lady in a year", and he prays, "may her future and yours justify us in 
the judgment which we have pronounced this night!" (Doyle 1930: 650). He opposes Victorian principles and the legal system when he hints the possible reunion of the Captain and Lady Brackenstall in the future. In the end of the story, the murderer is released and even let free to marry Lady Brackenstall, which would not be possible under circumstances in the Victorian age. In this way, Holmes conceals this murder and takes a revenge from the injustice and abusive men like Lord Brackenstall.

In the same manner as in the situation of Captain Crooker in "The Adventure of Abbey Grange", Holmes reacts similarly to Dr. Leon Sterndale in "The Devil's Foot". Dr. Sterndale is revealed as the murderer of Mortimer Tregennis who has poisoned his lover and her brothers for revenge against losing a family inheritance. However, Dr. Sterndale explains that he wanted to avenge the murder of his lover with whom he could not share a life. He could never marry her, for he could not get a divorce because of "the deplorable laws of England" (Doyle 1930: 968) although his wife had left him years ago. In addition, his action can be seen as an attack against British laws, and Holmes and Watson let him go even though he has committed murder. His longstanding unhappiness because of strict British laws makes them pity for him and enable his freedom. Dr. Sterndale's being extricated shows their anger and spite for the legal system because he should be punished as stated in laws. However, he has suffered a lot because of this legal system, so he is let free in opposition to British laws. Dr. Sterndale, by killing Mortimer, metes out justice which laws cannot bring forward. Just as he became a law to himself, Holmes takes the law into his own hands once again and exonerates him like he does for Captain Crooker.

Readers can observe Doyle's sympathy for people who suffered long because of stringent laws and conventions. Dr. Sterndale kills the murderer of his beloved whom he could never marry because of divorce laws in England. Being a victim of British laws, his motive is understood and justified by Holmes. Furthermore, the Captain kills Lord Brackenstall and saves his beloved from a vicious husband. In both cases, Holmes ironically breaks the law because the laws will not sympathize with them, so Doyle revolts against laws. He displays that laws will not feel empathy for these men, and they will suffer more unless they are let go and live their life freely. As Jina Moon (2016: 13) suggests, "[d] isappointed by the failures of the legislation, [...] Sir Arthur Conan Doyle" brings his own "justice to bear on perpetrators of domestic violence". In this way, he shows that sometimes it is necessary to act outside the law because British laws may victimize people and disregard their suffering.

\section{Conclusion}

In "The Adventure of Abbey Grange", Doyle portrays Victorian conventions that leave women dependent and submissive to men. For instance, after Lord Brackenstall is dead, another man enters Lady Brackenstall's life to save and marry her. Some scholars mentioned earlier in this article has accused Doyle of emphasizing the superiority of men in women's lives, he nonetheless portrays two different types of men. One is cruel and abusive Lord Brackenstall, and the other one is loving and gallant Captain Crocker. Therefore, Doyle indicates that men should treat women equally, not cruelly. Whereas he seems to advocate women's necessity to rely on men for protection and safety, it can be read as his urge for men to become considerate 
and kind to women. Doyle seems to sustain gender stereotypes, yet his works should not be stigmatized for showing only powerful men in women's lives. In fact, Sherlock Holmes stories seek to unveil the conditions of women and restrain male violence against women. In "The Devil's Foot", Doyle pictures a man rendered helpless because of legal procedures in marriage and divorce as well, so he intends to clarify the severity these laws for men and women.

Doyle makes the reader ponder the effects of Victorian moral certitudes on legal and social issues, including the rights of women. He puts forward that Victorian laws concerning domestic violence and divorce were not reformed enough. Moreover, public attention is inefficient for the legal reforms for especially the situation of women. Bringing poetic justice to perpetrators of wife battery, he suggests that abusive husbands should not be pardoned and tolerated but punished unconditionally. While Doyle dwells on the inadequacy of laws that are supposed to protect women, he points out the fact that domestic violence is not limited to working class districts. Furthermore, he denounces laws about these issues; however, he endorses the ideals of marriage and family at the same time. He stresses the significance of mutual respect and forbearance between men and women as prerequisites for a marriage. Deep rooted beliefs about gender stereotypes do not only pertain to the Victorian age, but they are clearly manifested in women's legal rights and the double standard in that period. As Doyle highlights, wife abuse is a problem because of domestic principles which promote a patriarchal order. He pinpoints that physical or social differences between sexes should not generate gender bias and inequality. That is, if marital laws and the ideology devaluing women are not transformed, conjugal problems cannot be overcome.

\section{Ethical Statement}

According to the author's statement, scientific, ethical and quotation rules were followed in the writing process of the study named "Domestic Violence and Divorce in Sherlock Holmes Stories"; according to ULAKBIM TR DIZIN criteria, there was no need for data collection in the study requiring ethics committee approval.

\section{References}

Belsey, Catherine (1994). "Deconstructing the Text: Sherlock Holmes". Sherlock Holmes: The Major Stories with Contemporary Critical Essays. Ed. John A. Hodgson. Boston: BedfordSt. Martin's. 381-388.

Doyle, Arthur Conan (1930). The Complete Sherlock Holmes. New York: Doubleday \& Company, Inc.

Favor, Lesli J. (2000). "The Foreign and the Female in Arthur Conan Doyle: Beneath the Candy Coating." English Literature in Transition, 1880-1920, 43 (4): 398-409. https://www.muse.jhu.edu/article/367466 [25.12.2020].

Foyster, Elizabeth (2005). Marital Violence: An English Family History, 1600-1857. Cambridge: Cambridge University Press. 
Frank, Lawrence (1996). "Dreaming the Medusa: Imperialism, Primitivism, and Sexuality in Arthur Conan Doyle's 'The Sign of the Four' ". Signs: Journal of Women and Culture in Society, 2 (21): 52-85. https://www.jstor.org/stable/3175041 [11.02.2021].

Frost, Ginger (2008). “ 'He Couldn't Hold His Passion': Domestic Violence and Cohabitation in England". Crime, Histoire, and Sociétés / Crime, History, and Societies, 12 (1): 45-63. http://journals.openedition.org/chs/64 [17.12.2020].

Haynsworth, Leslie (2001). "Sensational Adventures: Sherlock Holmes and His Generic Past". English Literature in Transition 1880-1920, 44 (4): 459-485. https://www.muse.jhu.edu/article/366592 [28.01.2021].

Hodgson, John A. (2010). "Arthur Conan Doyle (1859-1930)". A Companion to Crime Fiction. Ed. Charles J. Rzepka \& Lee Horsley. Oxford: Blackwell Publishing. 390-402.

Lycett, Andrew (2007). Conan Doyle: The Man Who Created Sherlock Holmes. London: Wedenfield \& Nichols.

Moon, Jina (2016). Domestic Violence in Victorian and Edwardian Fiction. Newcastle Upon Tyne: Cambridge Scholars Publishing.

O'Day, Alan (1979). The Edwardian Age: Conflict and Stability 1900-1914. London and Basingstoke: The Macmillan Press Ltd.

Perkin, Joan (1989). Women and Marriage in Nineteenth-Century England. London: Routledge.

Redmond, Christopher (1984). In Bed with Sherlock Holmes: Sexual Elements in Arthur Conan Doyle's Stories of the Great Detective. Canada: Simon \& Pierre.

Savage, Gail L. (1983). "The Operation of the 1857 Divorce Act, 1860-1910 A Research Note". Journal of Social History, 16 (4): 103-110. https://doi.org/10.1353/jsh/16.4.103

Surridge, Lisa E. (2005). Bleak Houses: Marital Violence in Victorian Fiction. Athens, Ohio: Ohio University Press. 